\title{
Method for obtaining high-resolution proteomic analysis from pericarps of guarana
}

\author{
A.L. Souza ${ }^{1}$, P.C.S. Angelo ${ }^{2}$, P.P.O. Nogueira ${ }^{3}$, J.F.C. Gonçalves ${ }^{4}$, \\ A.M. Franco ${ }^{4}$, S. Astolfi-Filho ${ }^{1}$, J.L. López-Lozano ${ }^{5}$ and E.V. Andrade ${ }^{1}$ \\ ${ }^{1}$ Centro de Apoio Multidisciplinar, Laboratório de Biologia Molecular, \\ Universidade Federal do Amazonas, Manaus, AM, Brasil \\ ${ }^{2}$ EMBRAPA Amazônia Ocidental, Manaus, AM, Brasil \\ ${ }^{3}$ Fundação Osvaldo Cruz, Manaus, AM, Brasil \\ ${ }^{4}$ Instituto Nacional de Pesquisas da Amazônia, Manaus, AM, Brasil \\ ${ }^{5}$ Fundação de Medicina Tropical do Amazonas, Manaus, AM, Brasil \\ Corresponding author: E.V. Andrade \\ E-mail: edandrade@ufam.edu.br / edandrade2003@yahoo.com.br
}

Genet. Mol. Res. 13 (3): 8014-8024 (2014)

Received September 12, 2013

Accepted December 17, 2013

Published September 29, 2014

DOI http://dx.doi.org/10.4238/2014.September.29.14

\begin{abstract}
Guarana has great agricultural potential and is largely used therapeutically and in the production of non-alcoholic energy drinks. Genomic and proteomic studies are crucial to identify proteins that play central roles in the maintenance and viability of fruits, as well as to identify proteins related to the main metabolic pathways. However, the success of any protein analysis starts with the protein extract preparation, which needs to offer an extract that is free of contaminants. This study aimed to evaluate different extraction methods to obtain high-quantity and high-quality extracts that are compatible with analysis by 2-dimensional electrophoresis and tandem mass spectrometry protein identification. Three different methods were tested: trichloroacetic acid (TCA)/acetone, sodium dodecyl sulfate (SDS)/phenol, and polyvinylpolypyrrolidone (PVPP)/SDS/phenol. The extract obtained from the TCA/acetone precipitation presented low solubility and contamination with lipids and carbohydrates. On the
\end{abstract}


other hand, the quality of the extract gradually improved after using phenol and PVPP/phenol, enabling a yield up to $2 \mathrm{mg} / \mathrm{g}$ macerated tissues and the detection of 457 spots by 2-dimensional electrophoresis. The effectiveness of the procedure used was validated by identification of 10 randomly selected proteins by mass spectrometry. The procedure described here can be a starting point for applications using tissues of other organs of guarana or tissues of species that are similar to guarana.

Key words: Plant proteomics; Two-dimensional electrophoresis; Polyphenols

\section{INTRODUCTION}

Guarana, Paullinia cupana (Kunth) var. sorbilis (Mart.) Ducke, is a rainforest vine that is widely used in traditional (Mendes and Carlini, 2007) and clinical medicine (de Oliveira Campos et al., 2011; Rodrigues et al., 2012b; Portella et al., 2013). Besides, the extracts from roasted guarana seeds are used for the production of non-alcoholic energy drinks (McLellan and Lieberman, 2012). Because of its great economical relevance, a better understanding of its physiology and secondary metabolism has been sought from different approaches. Previous studies of the guarana fruits with seeds identified several transcripts encoding enzymes and proteins that participate in biosynthetic routes, such as caffeine synthesis and important physiological processes including those related to plant-pathogen interactions (Ângelo et al., 2008; Figueirêdo et al., 2011). The increased knowledge about these sequences and their proteins can facilitate obtaining products from guarana for health applications (Costa et al., 2011) and developing plants with valuable agronomic traits. However, transcriptome analysis is not enough to obtain a complete picture of all the cellular processes that occur in complex organisms like eukaryotes. Proteomic studies offer a good approach to follow those results (Quiala et al., 2012) and to identify proteins that play central roles in the maintenance and viability of fruits when facing diverse environmental conditions. However, the success of any protein analysis starts with the protein extract preparation, and the ideal method must capture the greatest amount of protein while minimizing degradation and contamination by non-protein content (Isaacson et al., 2006; Jorrín-Novo et al., 2009).

Vegetal tissues have biochemical properties that can impair the use of general methods for protein extraction. Because of the biochemical heterogeneity, large amounts of proteases and oxidative enzymes, and the presence of non-protein contaminants can disturb the subsequent steps in proteomic approaches (Boonmee et al., 2011; Witzel et al., 2011). Therefore, there is not a universal protocol for extraction or a solvent that can capture an entire proteome, and adjustments to previously described protocols are required (Prinsi et al., 2011; Chatterjee et al., 2012; Rodrigues et al., 2012a; Zhang et al., 2012).

Guarana has high levels of oxidative enzymes, phenol, nitrogen, and terpene compounds, which hinder the application of methods for protein extraction that were developed in other species. Similar difficulties were reported by Wang et al. (2003), who observed that when proteins of the olive leaf were extracted by direct homogenization in aqueous buffer and precipitated in organic solvent, polyphenols and other contaminants were adsorbed 
to the proteins, which caused the pellet to darken due to oxidation. This contamination hampers subsequent dissolution, making the protein extract unsuitable for 2-dimensional electrophoresis (2-DE) analysis. A very efficient method involves the dissolution of proteins in phenol and precipitation in ammonium acetate in methanol (Hurkman and Tanaka, 1986). This method was successfully used for coffee (Franco et al., 2009), olive leaves (Wang et al., 2003), and other recalcitrant tissues such as those from tomato, avocado, and orange peel (Saravanan and Rose, 2004), as well as banana, apple, and potato (Carpentier et al., 2005). Despite the description of various biological properties of guarana and significant amounts of information that were obtained from its transcriptome, proteomic profiles from the different fruit tissues in the various developmental phases have not been reported. Therefore, the establishment of a reproducible protocol to prepare protein extracts from guarana is expected to be useful. In this study, we present the results from trials of already reported methods and a modified method, which ensured the achievement of high-quality guarana total protein extracts for use in 2-DE and the identification of spots by mass spectrometry (ESI Q-TOF-MS).

\section{MATERIAL AND METHODS}

\section{Plant material}

The BRS-Amazonas cultivar of guarana [(P. cupana (Kunth) var. sorbilis (Mart.) Ducke] was developed and is maintained at the Germplasm Bank of Embrapa Western Amazon $\left(3^{\circ} \mathrm{S}, 60^{\circ} \mathrm{W}, 50 \mathrm{~m}\right.$, Manaus, Amazonas, Brazil). Open-pollinated fruits from healthy plants were collected $15 \pm 7$ days after pollination, dissected in pericarps, arils and seeds, conditioned on dry ice, and transported for storage at $-80^{\circ} \mathrm{C}$. For total protein extraction, $1 \mathrm{~g}$ green pericarp was crushed in the presence of liquid nitrogen using a pre-cooled pestle and mortar until a fine powder was formed. Three procedures were tested in order to obtain suitable protein extracts from guarana pericarps and are schematically described in Figure 1.

\section{Protein extraction methods}

\section{Trichloroacetic acid $($ TCA)/acetone}

The TCA/acetone precipitation was carried out as described by Isaacson et al. (2006). Briefly, the powder was resuspended in $10 \mathrm{~mL}$ solution I [10\% (v/v) TCA; 2\% (v/v) 2-mercaptoethanol in cold acetone]. The mixture was incubated overnight at $-20^{\circ} \mathrm{C}$ and centrifuged (30 min at $5000 \mathrm{~g}$ and $4^{\circ} \mathrm{C}$ ). The pellet was washed with $10 \mathrm{~mL}$ cold acetone and centrifuged $\left(10 \mathrm{~min}\right.$ at $4000 \mathrm{~g}$ and $\left.4^{\circ} \mathrm{C}\right)$. The supernatant was discarded, and the wash step was repeated twice. During the wash steps, the sample was divided into 2 fractions: a heavy fraction that sedimented spontaneously and a light fraction (supernatant) that was less dense and required centrifugation to precipitate. At the last wash step the light fraction was transferred to microtubes ( $1-\mathrm{mL}$ aliquots), centrifuged $\left(10 \mathrm{~min}\right.$ at $4000 \mathrm{~g}$ and $\left.4^{\circ} \mathrm{C}\right)$, dried at room temperature for $20 \mathrm{~min}$, and stored at $-20^{\circ} \mathrm{C}$. Likewise, the heavy fraction was submitted to centrifugation and dried as described above and submitted to the second protein extraction method, sodium dodecyl sulfate (SDS)/phenol, which is described below. 


\section{SDS/phenol}

The SDS/phenol method was conducted as reported by Wang et al. (2003), with modifications. The heavy fraction that was obtained from the TCA/acetone precipitation was homogenized in $10 \mathrm{~mL}$ cold solution II [10\% (v/v) TCA in acetone]. The mixture was sonicated at a frequency of $22.5 \mathrm{kHz}$ ( 3 pulses of $20 \mathrm{~s}$ at 1-min intervals) in an ice bath using the ultrasound Fisher 100 Sonic Dismembrator. The re-precipitation of proteins was obtained by incubating the solution at $-20^{\circ} \mathrm{C}$ for $40 \mathrm{~min}$ and centrifugation $\left(30 \mathrm{~min}\right.$ at $4000 \mathrm{~g}$ and $4^{\circ} \mathrm{C}$ ). The pellet was washed twice with $10 \mathrm{~mL}$ ice-cold acetone, centrifuged ( $10 \mathrm{~min}$ at $4000 \mathrm{~g}$ and $4^{\circ} \mathrm{C}$ ), dried at room temperature, and separated into aliquots of $0.15 \mathrm{~g}$. The aliquots were solubilized in $0.6 \mathrm{~mL}$ solution III $[30 \%(\mathrm{w} / \mathrm{v})$ sucrose; $2 \%(\mathrm{w} / \mathrm{v}) \mathrm{SDS} ; 0.1 \mathrm{M}$ Tris-HCl, $\mathrm{pH} 7.5$; and $2 \%$ (v/v) 2-mercaptoethanol]. The mixture was homogenized with a vortex for $30 \mathrm{~s}$ and left at room temperature for $15 \mathrm{~min}$. Next, $0.6 \mathrm{~mL}$ saturated phenol in Tris- $\mathrm{HCl}, \mathrm{pH} 7.5$, was added, and the samples were agitated in a vortex for $20 \mathrm{~s}$ for protein solubilization, incubated for 5 $\mathrm{min}$ at room temperature, and centrifuged $\left(5 \mathrm{~min}\right.$ at $10,000 \mathrm{~g}$ and $\left.4^{\circ} \mathrm{C}\right)$. The phenol phase was recovered and added to 3 volumes solution IV [0.1 M ammonium acetate in methanol] and precipitated for $1 \mathrm{~h}$ at $-20^{\circ} \mathrm{C}$. The proteins were recovered by centrifugation $(10 \mathrm{~min}$ at 10,000 $g$ and $4^{\circ} \mathrm{C}$ ) and washed 3 times with 2 volumes cold methanol. The pellet was dried at room temperature for $15 \mathrm{~min}$ and stored at $-20^{\circ} \mathrm{C}$.

\section{Polyvinylpolypyrrolidone (PVPP)/SDS/phenol}

The PVPP/SDS/phenol procedure was carried out as a combination of steps described by Isaacson et al. (2006) and by Wang et al. (2003). The powder of guarana green pericarp was obtained as described above except for the addition of 5\% (w/w) PVPP during maceration to trap phenolic compounds, and it was homogenized in solution I. The samples were sonicated in an ice bath (as described above) and incubated at $-20^{\circ} \mathrm{C}$ for $40 \mathrm{~min}$ for protein precipitation. Proteins were recovered by centrifugation $\left(30 \mathrm{~min}\right.$ at $4000 \mathrm{~g}$ and $\left.4^{\circ} \mathrm{C}\right)$, washed twice with 10 $\mathrm{mL}$ ice-cold acetone, and centrifuged $\left(10 \mathrm{~min}\right.$ at $4000 \mathrm{~g}$ and $\left.4^{\circ} \mathrm{C}\right)$. The pellet was dried at room temperature for $15 \mathrm{~min}$ and separated into aliquots of $0.15 \mathrm{~g}$. The aliquots were solubilized in $0.6 \mathrm{~mL}$ solution III and treated as described for the SDS/phenol method.

\section{Protein quantification and 2-DE}

One aliquot of each extract was solubilized in $0.5 \mathrm{~mL} 3 \mathrm{M}$ urea, and the protein concentration was estimated using the bicinchoninic acid protein assay kit (BioAgency, Brazil) according to manufacturer instructions. The concentration of the proteins was determined by comparison with a standard curve $\left(y=0.002 x+0.0209 ; \mathrm{R}^{2}=0.9956\right)$ for bovine serum albumin. 2-DE was performed using a standard procedure (O'Farrell, 1975), with slight modifications. The aliquots $(250 \mu \mathrm{g})$ of proteins that were obtained from each extraction procedure described above were resuspended in $250 \mu \mathrm{L}$ DeStreak Rehydration Solution (GE Healthcare, Sweden) and 1\% immobilized $\mathrm{pH}$ gradient (IPG) buffer, $\mathrm{pH}$ 3-10 or 3-11 NL (GE Healthcare) and loaded onto an immobilized pH gradient strip (GE Healthcare, pH 3-10 NL or 3-11 NL) for overnight passive in-gel rehydration $(10 \mathrm{~h})$. Isoelectric focusing was performed at $20^{\circ} \mathrm{C}$ in an Ettan IPGPhor3 (GE Healthcare) with a continuous current of $50 \mathrm{~mA} /$ strip under the 
following conditions: $150 \mathrm{~V}$ for $2 \mathrm{~h}, 300 \mathrm{~V}$ for $2 \mathrm{~h}, 1000 \mathrm{~V}$ for $4 \mathrm{~h}$ (gradient), $8000 \mathrm{~V}$ for $2 \mathrm{~h}$ (gradient), and $8000 \mathrm{~V}$ for $2 \mathrm{~h}$. The proteins on the IPG strips were reduced and alkylated for the separation in the second dimension, which was performed on $12 \%$ SDS polyacrylamide gels in the SE600Ruby System (18 x $16 \mathrm{~cm}$, GE Healthcare) at $50 \mathrm{~mA}$ and $250 \mathrm{~V}$ for $4 \mathrm{~h}$. Polyacrylamide gels were fixed using $10 \%(\mathrm{v} / \mathrm{v})$ acetic acid and $40 \%(\mathrm{v} / \mathrm{v})$ methanol for $30 \mathrm{~min}$, followed by staining with colloidal Coomassie blue ( $8 \%$ ammonium sulfate, $0.8 \%$ phosphoric acid, $0.08 \%$ Coomassie blue G-250, and 20\% methanol) overnight and destaining with deionized water. Gels were scanned (Image Scanner, GE Healthcare), and the images were analyzed with the Image Master Platinum software (Version 6). Spot counts were obtained according to the saliency and smooth parameters, which were equal to 100 and 2, respectively. Three reproducible gels (over $70 \%$ similarity) were run corresponding to at least 2 independent extraction procedures from the PVPP/SDS/phenol extraction method. The gel with the highest number of spots was regarded as the reference gel.

\section{Protein identification by ESI Q-TOF-MS}

Ten protein spots that were taken randomly from the map obtained from the PVPP/ $\mathrm{SDS} /$ phenol extraction were subjected to tryptic in-gel digestion (sequencing grade-modified trypsin, lot: 24247001; Promega, USA), according to Hanna et al. (2000), and analyzed by MS. An aliquot $(4.5 \mu \mathrm{L})$ of the resulting peptide mixture was separated by $\mathrm{C} 18$ ( $75 \mu \mathrm{m}$ x $100 \mathrm{~mm}$ ) nanoACQUITY UltraPerformance LC (UPLC) System (Waters, UK) coupled with a Q-TOF Ultima mass spectrometer (Waters) with nano-electrospray source at a flow rate of $0.6 \mathrm{~mL} / \mathrm{min}$. The gradient was $2-90 \%$ acetonitrile in $0.1 \%$ formic acid over $20 \mathrm{~min}$. The instrument was operated in the "top three" mode, in which one MS is acquired followed by tandem MS of the top three most intense peaks that were detected. The resulting spectra were processed using Mascot Distiller 2.2.1.0, 2008, Matrix Science (MassLynx V4.1) and searched against guarana's expressed sequence tags database (available at http://www. ncbi.nih.gov) using Mascot, with carbamidomethylation as a fixed modification, oxidation of methionine and 1 trypsin missed cleavage, and a tolerance of $0.1 \mathrm{Da}$ for both precursor and fragment ions.

\section{RESULTS AND DISCUSSION}

\section{Protein yield and evaluation of 2-DE gels}

In an attempt to obtain guarana protein extracts that were free of interfering compounds for applications in proteomic analysis, 3 different procedures were evaluated in terms of protein yield and number and resolution of spots (Figure 1). The protein yield of the extracts obtained by the TCA/acetone, SDS/phenol, and PVPP/SDS/phenol methods was 1.81, 0.29 and 2.45 $\mathrm{mg} / \mathrm{g}$ macerated tissues, respectively. The sum of protein content obtained from the TCA/acetone and the SDS/phenol methods was $2.1 \mathrm{mg}$ protein $/ \mathrm{g}$ tissue, which was comparable to the protein content that was extracted with the PVPP/SDS/phenol method. These results indicate that the modifications that we introduced and the addition of PVPP during tissue maceration to trap phenolic compounds improved the protein yields from guarana pericarps by 1.4- and 8.4fold compared to the TCA/acetone and SDS/phenol methods, respectively. 


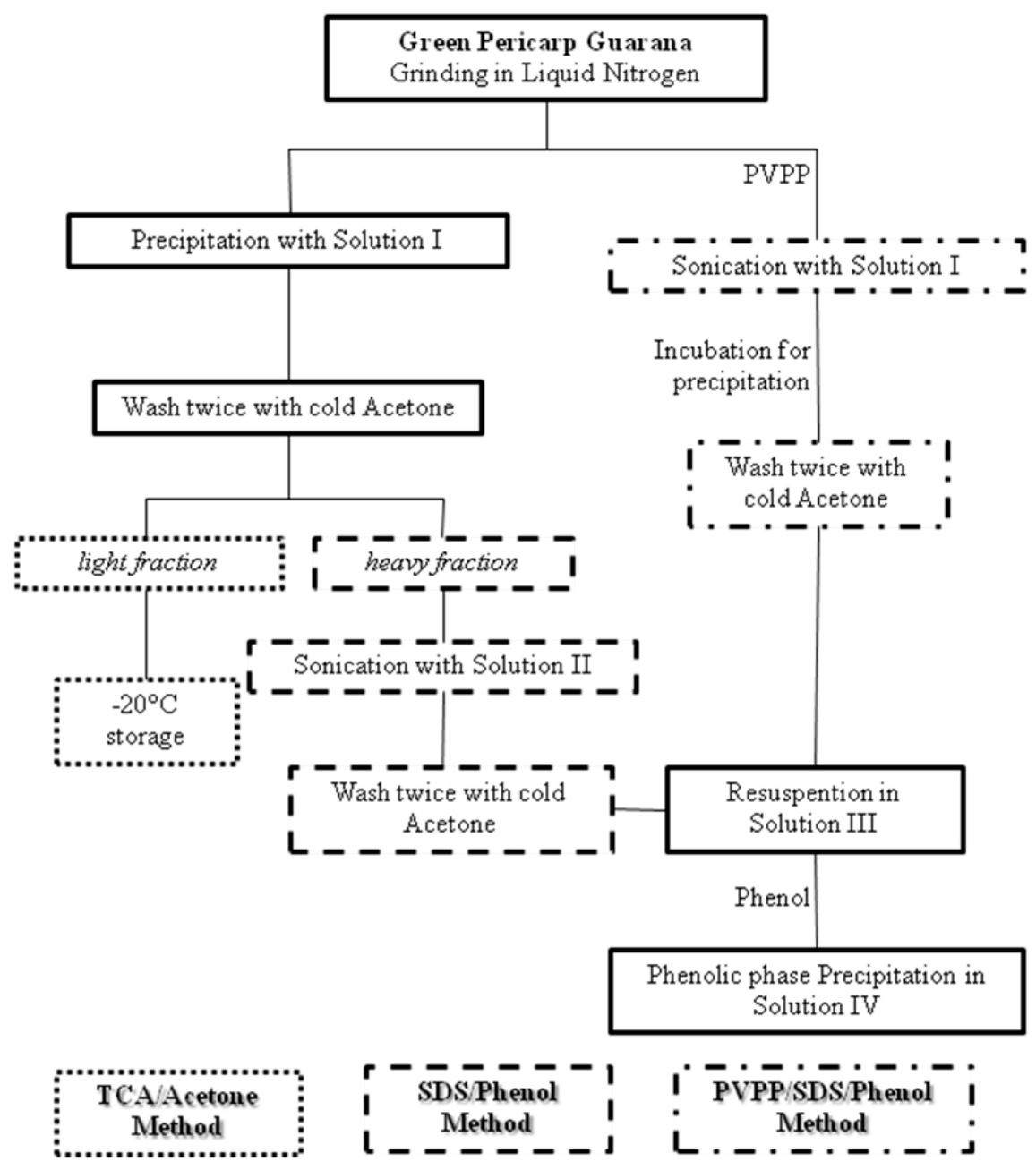

Figure 1. Schematic representation of 3 methods used to extract protein from guarana pericarps. Steps that were used for at least 2 procedures are represented in solid-lined boxes. Steps that were specific to a single procedure are represented by different types of dotted lines. $\mathrm{PVPP}=$ polyvinylpolypyrrolidone; TCA $=$ trichloroacetic acid; SDS $=$ sodium dodecyl sulfate.

Wang et al. (2003) reported that when proteins were extracted from olive leaves by direct homogenization in aqueous buffer and precipitation in organic solvent, polyphenols and other contaminants were adsorbed to the proteins, which caused the pellet to darken due to oxidation. Similar results were observed for guarana pericarps. The TCA/acetone method resulted in pellets with low solubility in aqueous buffer and a slightly yellowish color (data not shown), possibly due to the presence of pigments. The low solubility in water is likely caused by precipitation in the presence of TCA and acetone, as described by Nandakumar et al. (2003). On the other hand, the pellets that were obtained by the SDS/phenol and PVPP/SDS/ phenol methods were easily dissolved in inorganic buffer and were whitish in color (data not 
shown), which was expected for minor oxidation. For some species, such as papaya, however, the TCA method resulted in the highest protein yield compared with the phenol-based methods (Rodrigues et al., 2009). These data reinforce that there is not a common procedure for protein extract preparation from plant tissues.

The total number of spots that were detected with the TCA/acetone, SDS/phenol, and PVPP/SDS/phenol methods was 135, 271, and 457, respectively (Figure 2). Treating the macerated tissue with TCA in acetone is important to inhibit proteases and efficiently remove salts and polyphenols that are soluble in organic solvents (Nandakumar et al., 2003) because they interfere with the isoelectric focusing. However, as can be observed in Figure 2A, this treatment was not sufficient to eliminate carbohydrates and lipids from green pericarps of guarana, which blocked gel pores and caused the spots to smear. Besides the presence of non-protein contents in the sample, the low solubility probably contributed to the lower number of spots after the TCA/acetone precipitation. The contaminants were only removed after dissolution in phenol, which resulted in better solubility of the sample and an improved migration profile following 2-DE. However, the resolution was still compromised by the presence of vertical stripes, mainly in the alkaline region of the gel (Figure 2B). This was probably a consequence of the presence of phenolic compounds in the protein extract, which reversibly (by hydrogen bonds) or irreversibly (by oxidation) bind to proteins, leading to heterogeneity of the sample charges and smearing on the gel (Carpentier et al., 2005). These phenolic compounds were completely removed only by the use of PVPP during the maceration of tissues, preventing the oxidation of proteins (Isaacson et al., 2006). The improved quality of the protein extract was defined by the striking reduction in the horizontal smears and vertical stripes, and by the number of detected spots (Figure 2C), which was approximately 3- and 1.6-fold higher than those from the TCA/acetone precipitation and SDS/phenol methods, respectively. Because one of the main bottlenecks for a successful proteomic approach is the richness and resolution of the spots, these results indicate that PVPP/SDS/phenol is the best method to obtain high-yield and high-quality protein extracts from guarana pericarps.

\section{Protein identification by ESI Q-TOF-MS}

Proteins that were identified by ESI Q-TOF-MS are indicated in Figure 2C (arrows) and listed in Table 1. For some identified proteins, there were differences between the observed and the theoretical molecular weight and isoelectric point, which could be due to posttranslational modifications. Proteins that were identified in this study included the following: enolase (spot 1), glyceraldehyde-3-phosphate dehydrogenase C subunit (spot 2), photosystem II oxygen-evolving complex 33-kDa subunit (spot 3), ascorbate peroxidase (APX, spot 4), 23-kDa oxygen-evolving protein of photosystem II (spot 5), major latex-like protein (spot 6), cyclophilin (spot 7), histone $2 \mathrm{~b}$ (spot 8), superoxide dismutase (spot 9), and lectin (spot 10).

Reactive oxygen species could be generated from different cellular processes in plants such photosynthetic metabolism and oxidative stress (Shine and Guruprasad, 2012). Superoxide dismutase contributes during protection against oxidative stress (Waters et al., 2012), promoting the dismutation of superoxide radicals that produce hydrogen peroxide, which is mainly removed by APX in plant cells (Klein et al., 2012; Suzuki et al., 2013). In this reaction, APX catalyzes the reduction of $\mathrm{H}_{2} \mathrm{O}_{2}$ to $\mathrm{H}_{2} \mathrm{O}$ through the oxidation of ascorbate (ASC) to monohydroascorbate, which will be reduced again to ASC in the glutathione-ASC cycle (Damanik et al., 2010). APX contributes to the response to abiotic stress factors, such as heat and light (Suzuki et al., 2013). 
A
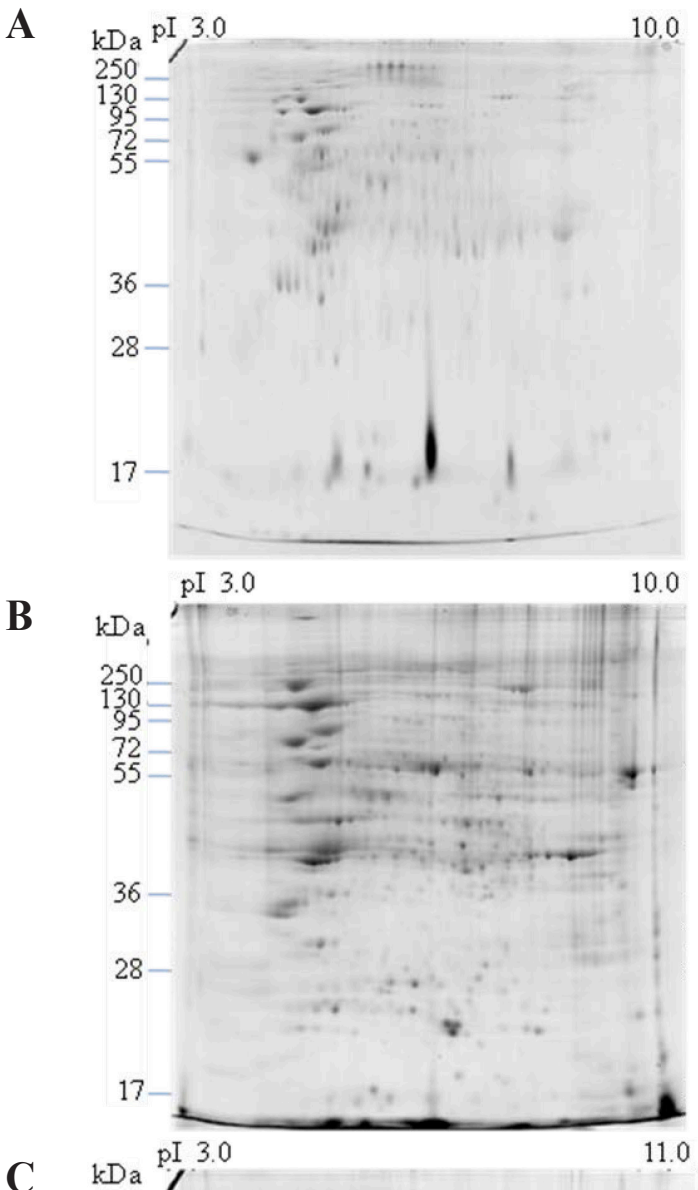

C

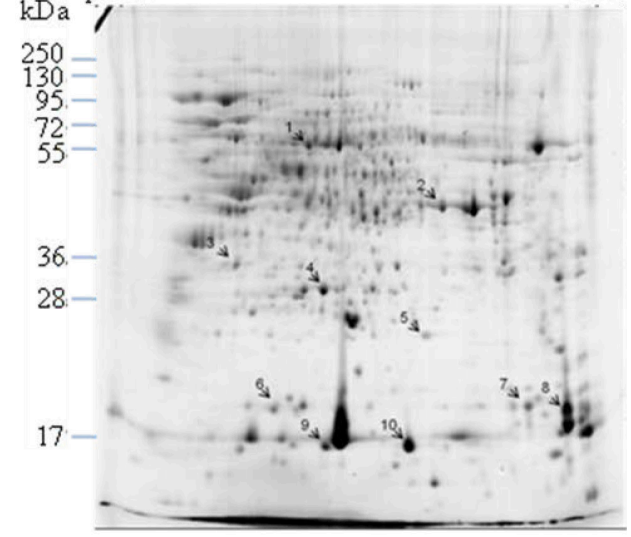

Figure 2. Proteomic map from the green pericarp of guarana. Protein extracts were prepared using A. trichloroacetic acid (TCA)/acetone; B. sodium dodecyl sulfate (SDS)/phenol; and C. polyvinylpolypyrrolidone (PVPP)/SDS/ phenol methods. The isoelectric focusing was performed on a $13-\mathrm{cm}$ strip followed by SDS-polyacrylamide gel electrophoresis on a $12 \%$ gel. Visualization was performed by staining with colloidal Coomassie blue. For all gels, $250 \mu \mathrm{g}$ protein was used. Arrows in $\mathrm{C}$ indicate the spots that were selected for mass spectrometry identification. 
Table 1. Proteins identified by mass spectrometry.

\begin{tabular}{lccrlr}
\hline Spot No. & pI/MW $(\mathrm{kDa})$ Exp & $\mathrm{pI} / \mathrm{MW}(\mathrm{kDa})$ Theo & Score & Protein ID & Database ESTs \\
\hline 1 & $5.48 / 26.5$ & $5.56 / 47.9$ & 132 & Enolase & 3,310 \\
2 & $9.37 / 20.2$ & $7.7 / 36.5$ & 84 & Glyceraldehyde-3-phosphate dehydrogenase C subunit & 3,105 \\
3 & $5.23 / 22.3$ & $5.85 / 35.2$ & 637 & Photosystem II oxygen-evolving complex 33-kDa subunit & 10,697 \\
4 & $5.77 / 22.7$ & $5.64 / 27.4$ & 168 & Ascorbate peroxidase & 401 \\
5 & $8.42 / 22.9$ & $8.27 / 28.0$ & 51 & 23 -kDa oxygen-evolving protein of photosystem II & 2,730 \\
6 & $6.2 / 15.4$ & $5.46 / 17.1$ & 34 & Major latex-like protein & 13,126 \\
7 & $8.9 / 19.5$ & $8.69 / 18.1$ & 138 & Cyclophilin & 1,157 \\
8 & $10.3 / 20.5$ & $10.1 / 15.8$ & 195 & Histone 2b & 14,467 \\
9 & $7.3 / 25.0$ & $5.77 / 15.1$ & 185 & Superoxide dismutase & 3,922 \\
10 & $8.8 / 19.4$ & $6.0 / 47.5$ & 218 & Lectin & 9,625 \\
\hline
\end{tabular}

Names, theoretical (Theo) and experimental (Exp) values for the isoelectric points (pIs) and molecular weights (MW), and expressed sequence tags (ESTs) of each identified protein are indicated. The scores were obtained from the National Center for Biotechnology Information.

Enolase (2-phospho-D-glycerate hydrolase) is an essential glycolytic enzyme that catalyzes the interconversion of 2-phosphoglycerate and phosphoenolpyruvate. This enzyme was differentially expressed in seeds of Lolium rigidum, and the authors discussed its role in thermotolerance during mechanisms of dormancy induction and release (Goggin et al., 2011). The glyceraldehyde-3-phosphate dehydrogenase $\mathrm{C}$ subunit plays an important role in glycolysis by providing ATP and NADH to cells, and it contributed to non-glycolytic processes in Arabidopsis thaliana and was modulated by posttranslational modifications (Bedhomme et al., 2012; Wojtera-Kwiczor et al., 2013).

Photosystem II is an important multiprotein oxygen-evolving complex that is located in the thylakoid membranes of chloroplasts. The contribution of different proteins including the photosystem II oxygen-evolving complex 33-kDa subunit on this photosynthetic electron transport chain, which can produce oxygen from water and light, has been vastly demonstrated (Millaleo et al., 2013). In young plants of 2 guarana clones that were grown in conditions of light stress, the greater activity involving photochemical processes (high-electron transport rate) in the tolerant clone contributed to a more significant decrease in the degree of photoinhibition compared to the sensitive clone.

The major latex-like protein, which is found in the aqueous matrix of latex, has an unknown function (Sun et al., 2010). However, its similarity to proteins that are related to pathogenesis suggests its involvement in defense against phytopathogens. Cyclophilin, which is found in plants, fungi, and bacteria, presents cis-trans-prolyl peptide isomerase activity that catalyzes the rotation of peptide bonds at the amino end of proline residues (Trandinh et al., 1992). Additionally, the action of cyclophilin as an ATP-independent molecular chaperone has been described (Ellis and van der Vies, 1991). The lectins are a specialized group of proteins that can bind and precipitate carbohydrates. They are ubiquitously distributed in plants, animals, and fungi, and they are involved in diverse biological processes including the defense system in plants (Peumans and Van Damme, 1995). This group also includes a class of carbohydrate-binding proteins of non-immune origin that was identified in mistletoe, ricin and concavalin A, and a lectin from Polygonatum cyrtonema that acts in cancer treatment by inducing apoptosis in cancer cells (Fu et al., 2011).

In conclusion, we developed an efficient procedure to extract total protein from guarana pericarps that uses PVPP and phenol. This procedure allows the production of highquality protein extracts that are suitable for proteomic analysis and identification of spots by 
MS. This procedure also efficiently prepares protein extracts from seeds (data not shown) and contributed to proteomic analyses of guarana seeds and pericarps at different stages of development that are in progress in our laboratory. According to the results presented in this study, we propose the procedure based on PVPP and phenol as the method to obtain protein extracts from plants that present biochemical characteristics that are similar to those of guarana, such as high levels of polyphenol, carbohydrate, and lipid contamination.

\section{ACKNOWLEDGMENTS}

Research supported by CNPq, FAPEAM, CAPES, and FINEP. This study was carried out by the Amazon Proteomic Network (PROTEAM). We thank the Mass Spectrometry Laboratory at Brazilian Biosciences National Laboratory, CNPEM-ABTLuS, Campinas, Brazil, for its support with the mass spectrometry analysis.

\section{REFERENCES}

Ângelo PC, Nunes-Silva CG, Brigido MM, Azevedo JS, et al. (2008). Guarana (Paullinia cupana var. sorbilis), an anciently consumed stimulant from the Amazon rain forest: the seeded-fruit transcriptome. Plant Cell Rep. 27: 117-124.

Bedhomme M, Adamo M, Marchand CH, Couturier J, et al. (2012). Glutathionylation of cytosolic glyceraldehyde3-phosphate dehydrogenase from the model plant Arabidopsis thaliana is reversed by both glutaredoxins and thioredoxins in vitro. Biochem. J. 445: 337-347.

Boonmee A, Srisomsap C, Chokchaichamnankit D, Karnchanatat A, et al. (2011). A proteomic analysis of Curcuma comosa Roxb. rhizomes. Proteome Sci. 9: 43.

Carpentier SC, Witters E, Laukens K, Deckers P, et al. (2005). Preparation of protein extracts from recalcitrant plant tissues: an evaluation of different methods for two-dimensional gel electrophoresis analysis. Proteomics 5: 2497-2507.

Chatterjee M, Gupta S, Bhar A and Das S (2012). Optimization of an efficient protein extraction protocol compatible with two-dimensional electrophoresis and mass spectrometry from recalcitrant phenolic rich roots of Chickpea (Cicer arietinum L.). Int. J. Proteomics 2012: 536963.

Costa KC, Ribeiro EE, Ribeiro EA, Moresco RN, et al. (2011). Habitual intake of Guarana and metabolic morbidities: An epidemiological study of an elderly Amazonian population. Phytother. Res. Doi: 10.1002/ptr.3437.

Damanik RI, Maziah M, Ismail MR, Ahmad S, et al. (2010). Responses of the antioxidative enzymes in Malasyan rice (Oryza sativa L.) cultivars under submergence condition. Acta Physiol. Plant 32: 739-747.

de Oliveira Campos MP, Riechelmann R, Martins LC, Hassan BJ, et al. (2011). Guarana (Paullinia cupana) improves fatigue in breast cancer patients undergoing systemic chemotherapy. J. Altern. Complement. Med. 17: 505-512.

Ellis RJ and van der Vies SM (1991). Molecular chaperones. Annu. Rev. Biochem. 60: 321-347.

Figueirêdo LC, Faria-Campos AC, Astolfi-Filho S and Azevedo JL (2011). Identification and isolation of full-length cDNA sequences by sequencing and analysis of expressed sequence tags from guarana (Paullinia cupana). Genet. Mol. Res. 10: 1188-1199.

Franco OL, Pelegrini PB, Gomes CP, Souza A, et al. (2009). Proteomic evaluation of coffee zygotic embryos in two different stages of seed development. Plant Physiol. Biochem. 47: 1046-1050.

Fu LL, Zhou CC, Yao S, Yu JY, et al. (2011). Plant lectins: targeting programmed cell death pathways as antitumor agents. Int. J. Biochem. Cell Biol. 43: 1442-1449.

Goggin DE, Powles SB and Steadman KJ (2011). Selection for low or high primary dormancy in Lolium rigidum Gaud seeds results in constitutive differences in stress protein expression and peroxidase activity. J. Exp Bot. 62: 1037-1047.

Hanna SL, Sherman NE, Kinter MT and Goldberg JB (2000). Comparison of proteins expressed by Pseudomonas aeruginosa strains representing initial and chronic isolates from a cystic fibrosis patient: an analysis by 2-D gel electrophoresis and capillary column liquid chromatography-tandem mass spectrometry. Microbiology 146: 2495-2508.

Hurkman WJ and Tanaka CK (1986). Solubilization of plant membrane proteins for analysis by two-dimensional gel electrophoresis. Plant Physiol. 81: 802-806.

Isaacson T, Damasceno CM, Saravanan RS, He Y, et al. (2006). Sample extraction techniques for enhanced proteomic analysis of plant tissues. Nat. Protoc. 1: 769-774.

Jorrín-Novo JV, Maldonado AM, Echevarria-Zomeno S, Valledor L, et al. (2009). Plant proteomics update (2007-2008):

Genetics and Molecular Research 13 (3): 8014-8024 (2014)

CFUNPEC-RP www.funpecrp.com.br 
Second-generation proteomic techniques, an appropriate experimental design, and data analysis to fulfill MIAPE standards, increase plant proteome coverage and expand biological knowledge. J. Proteomics 72: 285-314.

Klein P, Seidel T, Stocker B and Dietz KJ (2012). The membrane-tethered transcription factor ANAC089 serves as redoxdependent suppressor of stromal ascorbate peroxidase gene expression. Front Plant Sci. 3: 247.

McLellan TM and Lieberman HR (2012). Do energy drinks contain active components other than caffeine? Nutr. Rev. 70: $730-744$.

Mendes FR and Carlini EA (2007). Brazilian plants as possible adaptogens: an ethnopharmacological survey of books edited in Brazil. J. Ethnopharmacol. 109: 493-500.

Millaleo R, Reyes-Díaz M, Alberdi M, Ivanov AG, et al. (2013). Excess manganese differentially inhibits photosystem I versus II in Arabidopsis thaliana. J. Exp. Bot. 64: 343-354.

Nandakumar MP, Shen J, Raman B and Marten MR (2003). Solubilization of trichloroacetic acid (TCA) precipitated microbial proteins via $\mathrm{NaOH}$ for two-dimensional electrophoresis. J. Proteome Res. 2: 89-93.

O’Farrell PH (1975). High resolution two-dimensional electrophoresis of proteins. J. Biol. Chem. 250: 4007-4021.

Peumans WJ and Van Damme EJ (1995). Lectins as plant defense proteins. Plant Physiol. 109: 347-352.

Portella RL, Barcelos RP, da Rosa EJ, Ribeiro EE, et al. (2013). Guarana (Paullinia cupana Kunth) effects on LDL oxidation in elderly people: an in vitro and in vivo study. Lipids Health Dis. 12: 12.

Prinsi B, Negri AS, Fedeli C, Morgutti S, et al. (2011). Peach fruit ripening: A proteomic comparative analysis of the mesocarp of two cultivars with different flesh firmness at two ripening stages. Phytochemistry 72: 1251-1262.

Quiala E, Cañal MJ, Rodríguez R, Yagüe N, et al. (2012). Proteomic profiling of Tectona grandis L. leaf. Proteomics 12: 1039-1044.

Rodrigues EP, Torres AR, da Silva Batista JS, Huergo L, et al. (2012a). A simple, economical and reproducible protein extraction protocol for proteomics studies of soybean roots. Genet. Mol. Biol. 35: 348-352.

Rodrigues M, Alves G, Lourenço N and Falcão A (2012b). Herb-drug interaction of Paullinia cupana (Guarana) seed extract on the pharmacokinetics of Amiodarone in rats. Evid. Based Complement. Alternat. Med. 2012: 428560.

Rodrigues SP, Ventura JA, Zingali RB and Fernandes PM (2009). Evaluation of sample preparation methods for the analysis of papaya leaf proteins through two-dimensional gel electrophoresis. Phytochem. Anal. 20: 456-464.

Saravanan RS and Rose JK (2004). A critical evaluation of sample extraction techniques for enhanced proteomic analysis of recalcitrant plant tissues. Proteomics 4: 2522-2532.

Shine MB and Guruprasad KN (2012). Oxyradicals and PSII activity in maize leaves in the absence of UV components of solar spectrum. J. Biosci. 37: 703-712.

Sun H, Kim MK, Pulla RK, Kim YJ, et al. (2010). Isolation and expression analysis of a novel major latex-like protein (MLP151) gene from Panax ginseng. Mol. Biol. Rep. 37: 2215-2222.

Suzuki N, Miller G, Sejima H, Harper J, et al. (2013). Enhanced seed production under prolonged heat stress conditions in Arabidopsis thaliana plants deficient in cytosolic ascorbate peroxidase 2. J. Exp. Bot. 64: 253-263.

Trandinh CC, Pao GM and Saier MH Jr (1992). Structural and evolutionary relationships among the immunophilins: two ubiquitous families of peptidyl-prolyl cis-trans isomerases. FASEB J. 6: 3410-3420.

Wang W, Scali M, Vignani R, Spadafora A, et al. (2003). Protein extraction for two-dimensional electrophoresis from olive leaf, a plant tissue containing high levels of interfering compounds. Electrophoresis 24: 2369-2375.

Waters BM, McInturf SA and Stein RJ (2012). Rosette iron deficiency transcript and microRNA profiling reveals links between copper and iron homeostasis in Arabidopsis thaliana. J. Exp. Bot. 63: 5903-5918.

Witzel K, Shahzad M, Matros A, Mock HP, et al. (2011). Comparative evaluation of extraction methods for apoplastic proteins from maize leaves. Plant Methods 7: 48.

Wojtera-Kwiczor J, Gross F, Leffers HM, Kang M, et al. (2013). Transfer of a redox-signal through the cytosol by redoxdependent microcompartmentation of glycolytic enzymes at mitochondria and actin cytoskeleton. Front Plant Sci. 3: 284.

Zhang LL, Feng RJ and Zhang YD (2012). Evaluation of different methods of protein extraction and identification of differentially expressed proteins upon ethylene-induced early-ripening in banana peels. J. Sci. Food Agric. 92: 21062115. 